\title{
Exploration on current college students' ideological characteristics and ideological and political coaching approaches HaO Li
}

\author{
Departments of Modern Science and Technology, Agricultural University of Hebei, Baoding, \\ 071000, China
}

Keywords: College students; Ideological characteristics; Ideological and political coaching; Coaching approaches

\begin{abstract}
Chinese colleges are an educational base where socialist constructors and successors are cultivated. Facing with diversified global pattern and diverse development trend of social economy at present, schools should improve level of ideological and political education to enhance construction of students' quality. Thus, it is quite necessary to explore coaching approaches of ideological and political education actively. This thesis explores current college students' ideological characteristics and ideological and political coaching approaches.

At present, economic competition becomes increasingly fierce in the world. To realize sustainable development of economy, China should adapt to requirements of global market and improve talent's competitive strength constantly. As a base where talent is cultivated, colleges should not only adapt to economic globalization and science and technology informatization but also survey impacts of political pluralization trend on economic development from the perspective of society and improve the degree to which college students attach importance to ideological and political education by this.
\end{abstract}

\section{Connotation of ideology}

Ideology is reflection of objective existence in people's mind, which is generated after the brain's thinking activities. People's ideology is reflected by their value and acts an important reflection of people's essential power. Ideology of people in the society is reflection of social relationship. When people live in the society, their ideology is established with social activities. With profound social foundation, ideology is generated in life and also has some effect on life.

People's ideology is featured by plasticity, which is not only reflected by the situation that it is inborn but also acts as creative results formed by absorption, analysis, processing and integration of external information more importantly. People's conformity instinct decides people have ability to accept external ideas in ideology. In addition, people’s ideology has independence and constant variability. Independence of ideology decides conflicts and divergence among people, which need be solved by improving ideological co-fusion. Constant variability of ideology is caused by impacts of external environment, which reflects people's ideology will progress with social development.

In short, people's ideology changes constantly. Because of change and independence of ideology, creativity will be improved. Plasticity of ideology will perfect people's existence value continuously.

\section{Ideological characteristics of current college students}

Individuals exist in entirety and will have influence on entirety inevitably. Overall ideological characteristics of college students are reflected by different college students. Research on college students' ideological behaviors by starting from their ideological characteristics just represents conclusion about college students' individual features and disclosure about college students' ideological changes and developmental directions, which is helpful for further research on ideological and political coaching approaches.

(I) Political quality of college students is stable overall and some students have political apathy With respect to political theory and thoughts, college students can deeply comprehend 
Marxism-Leninism, Mao Zedong Thought, Deng Xiaoping Theory and the Important Thought of Three Representatives and hold firm belief in the Party's leadership and socialist modernization with Chinese characteristics. Based on this, college students support China's reform overall and have high political consciousness commonly. They care for state affairs and learn current affairs and important news by channels like TV and internet. Especially, they have high political sensitivity to hot current affairs at home and abroad, which shows their enthusiasm for patriotism sufficiently. However, some college students have political apathy, deeming that politics is too far away from them and has no relationship with personal interests so that they do not need take it into consideration. This political apathy tends to cause weak political discriminability for students, makes students lack social responsibility and sense of mission and shakes socialist core value in students' mind.

(II) College students' consumption idea tends to be rational and style of luxury exists for some students

All contemporary college students will show positive attitude towards life. Although college students' source of income mainly derives from their parents', they actively devote themselves to social practice and spend spare time in taking up social public welfare activities, for instance, publicity, and also increase their income by virtue of work-study program. It is obviously that college students' independent survivability is enhanced generally. From the perspective of thought, college students may obtain living expenses via their effort and improve their living ability via the expression that they are independent from parents and live by themselves. At the same time, college students learn abstinence in consumption, establish rational consumption view and use the behavioral pattern, i.e., appropriate consumption, to realize maximization of consumption effectiveness when they experience difficulty in making money. However, vulgar extravagant style exists for college students. The main reason for this is that they are affected by blundering general mood of society. Frugality is a traditional virtue of Chinese nation. For college students without income, they will reduce their personality and dignity and even commit a crime to satisfy various luxuries if they pursue high-end life blindly. Such college students know principles about frugality, but they do not put it into practice. This sufficiently shows some college students have the negative attitude towards life at present, i.e., they pursue creature comfort excessively.

(III) College students pay attention to mental health but their ability of mental regulation has been insufficient

Contemporary college students have strong health consciousness so that they can treat study and life with good mentality. However, facing with pressure from app aspects, such as school record, employment pressure and emotion, some college students are unable to cope with them. As a result, they suffer fretted emotion. Establishing psychological health education not only adapts to current life pressure of college students at present but also can adjust their psychological disorder. Nevertheless, college students studying at universities often have psychological inversion which is different from that of middle school students. In detail, college students will show hate and horror because they lack sense of security. Generally, such college students' adaptive capacity to environment is poor. Once environment changes, they will be emotional and show strong negative attitude. In the aspect of behaviors, they confront persuasion with rebellious attitude. The more the persuasion is, the larger the degree to which they insist on their own opinions is.

\section{Ideological and political coaching approaches for college students at present}

(I) Starting from the perspective of theoretical education to develop ideological and political coaching to guide college students to establish positive consciousness

To develop ideological and political coaching for college students, it is essential to apply theory courses of ideological and political education. We may help college students to comprehend content of ideological and political education profoundly and relate it with Reform and Opening-up of China and socialist modernization with Chinese characteristics by developing subject construction of ideological theory, strengthening teachers and combining the knowledge imparted by teachers with ideological and political education. For college students, the main reason why they do not pay 
enough attention to ideological and political education is that theories in ideological and political education are so recondite that it is difficult to combine them with practical life. Then, when ideological and political education is carried out for students, ideological and political teachers should explore coaching approaches of ideological and political education deeply to change educational content into straightaway principles related to social reality. This means ideological and political teachers at colleges should implement innovation for coaching approaches of ideological and political education continuously according to college students' ideological characteristics in order to make coaching approaches of ideological and political education accord with students' demands practically and exert its ideological and political coaching effect.

(II) Starting from the perspective of Chinese traditional culture to develop ideological and political coaching to cultivate college students' national spirit

Chinese nation has had 5,000 years' history of civilization and its traditional culture is long-standing. As an expression of Chinese national spirit, Chinese traditional culture carries great spirit of Chinese nation and drives later generations to constantly strive to become stronger and exert themselves to make progress. Contemporary college students after the 1990s grow in a flourishing social era and stay in environment with fierce economic competition, so they are quite sensitive to economy. However, behind economic development, there is national spirit giving support. Chinese traditional culture shows Chinese nation's spiritual pursuit. Contemporary college students should be responsible for inheriting this essence of culture to improve their confidence, self-esteem and spirit of self-improvement. When colleges develop ideological and political education for their students, they should start from Chinese traditional culture education such an effective approach and carryout educational guidance, which can help students cultivate their moral character and morality. As Chinese economy develops, Chinese traditional culture is being adored by the world, while Chinese college students turn their eyes on stage of world economy. In order too maintain cultural heritage of China, we should use it as an approach of college students' ideological and political education and enable college students to know importance of combination between knowing and doing in traditional culture and implement in real life in order that they can comprehend practical significance of combination between individual behavior and moral theory deeply.

(III) Starting from the perspective of social practice to develop ideological and political coaching so as to cultivate college students' positive consciousness about life

Human essence is sum of social relations, while morality is a feature of people's social practicalness. This means teachers must start from the perspective of social practice and improve persuasion of ideological education in order to optimize college students' ideological opinions. For instance, teachers may spend holidays and festivals or winter and summer vacation in guiding college students to visit local history museums. On the one hand, this can enrich college students' spare-time culture life. On the other hand, students may cognize one aspect of social history and feel their current happy life is hard-won in their own heart. Thus, they will value what they have had to a larger extent. Meanwhile, this kind of social practical activities will make students feel the responsibilities that they should undertake. Thus, their sense of responsibility and sense of mission will be enhanced.

(IV) Starting from the perspective of example education to develop ideological and political coaching in order to give correct guidance to college students' values

Example education is education by positive examples. In detail, it gives correct ideological guidance to college students by setting up positive examples. When example education is developed, educational methods should keep pace with the times. Contemporary college students have their own opinions on both cognition about knowledge and opinions on things. Especially in the era when information technology drives development of knowledge economy, college students' spiritual pursuit and belief have been changed because of impacts of social environment. Therefore, example education for college students should not be limited to typical characters that they have been familiar with since they were young, such as Lei Feng and Kong Fansen, but look for characters with typical significance in reality to make students feel their examples are close to them. 
In doing so can students' positive and upward enthusiasm be aroused. For instance, excellent undergraduates' deeds that touch the heart of China and undergraduates' adverse events which affect the society seriously can be used to guide students to form correct values. When they contradict adverse events, they will start from the perspective of theory, survey problems existing in college students under current social background and analyze them rationally. In fact, it is teachers that have the most influence on college students, so it is required that teachers should be a model for students and improve their knowledge accomplishment and moral sentiments constantly. Their speech and deportment will form unconscious education for students. In addition, teachers may set up examples among college students, which will form goals for college students virtually and drives them to work hard towards a correct direction actively.

(V) Starting from the perspective of psychological education to develop ideological and political coaching in order to promote college students' physical and psychological health

The basis on which college students' ideological and political education is developed is to implement healthy psychological quality education for them and make them face with pressure and setbacks.

College students' psychological problems have become a problem that draws much attention from the society, which are mainly based on the situation that contemporary college students have to face with pressure from many aspects, such as learning pressure, employment pressure and economic pressure etc. For college students, they have not had powerful mental capability of adapting themselves. Thus, psychological burden is caused. Although university campus is isolated from the society, colleges themselves are a small society. When college students leaving their families enter university campus to start independent life, they need undertake everything they encounter independently. As several kinds of psychological burden cannot be eliminated, they tend to take extreme behaviors easily. The practice that colleges develop ideological and political work can adapt to students' demands. Schools should start from psychological education and permeate ideological and political education to it when they help students eliminate their mental burden. Meanwhile, teachers should guide students to know self-release and self-adjustment to remit their mental pressure when they face with difficulty and pressure. Timely guidance for students' psychological disorder can not only improve their personality charm but also avoid occurrence of various kinds of accidents in campus to a large extent.

\section{Conclusion:}

In conclusion, college students are main force of university campus. They stay under the large background of science and technology information and form new ideological characteristics because influence of social environment. In order to improve comprehensive quality of contemporary college students, it is essential too cultivate college students' excellent ideology and morality in addition to the requirement that college students should have strong professional skills and knowledge level in order that they can have good professional quality after they start their work in the society in future. Research on ideological and political coaching from common requirements of the society for talent and according to ideological characteristics of college students becomes an important task in the educational field of college students.

\section{Reference}

[1] Xu Jingjie. Features of high vocational college students and approaches of ideological and political education in the new era [J]. Education and Career, 2013(26).

[2] Wang Xiaoqian. Analysis of college students' ideological characteristics and approaches of ideological and political work innovation [J]. Extensive Collection of The Party History (Theoretical Edition), 2009(04).

[3] Chen Dan. Analysis of post-90s college students' ideological characteristics and response to approaches of ideological and political work [J]. Science and Technology Information, 2012(34).

[4] Ran Long, Dong Yan, Ding Yanhong. Analysis of post-90s college students' ideological 
characteristics and countermeasures about approaches of ideological and political education [J]. Reading and Writing Periodical, 2011:8(07).

[5] Zhou Xiaojun. Research on post-90s college students' ideological characteristics and countermeasures about approaches of ideological and political education [J]. Learning Theory, 2013(29).

[6] Song Qinghui, Gao Yonghui, Hanxia. Discussion on moral education of higher vocational students [J]. Journal of Shandong Youth Administrative Cadres College, 2008(01).

[7] Liao Lan, Li Jiandong. On post-90s college students' ideological characteristics — discussion on ways to carry out ideological and political education for contemporary college students [J]. Theory Observation, 2011(05).

[8] Wang Yao. New challenges brought by new media to post-90s college students' ideological and political education [J]. Ideological Education Research, 2010(01).

[9] Wu Zhuohua, Zhao Zhiping, Liu Ning, Zhang Xiaochen. Research on post-90s college students' ideological characteristics and educational countermeasures [J]. Journal of Shanghai Business School, 2010(05). 